\title{
Source/sink removal affects mobile carbohydrates in Pinus cembra at the Swiss treeline
}

Received: 14 May 2001 / Accepted: 10 January 2001 / Published online: 13 March 2002

(C) Springer-Verlag 2002

\begin{abstract}
Carbohydrate stores may hold the answer to the old question whether treeline trees are carbon limited. However, it is still unknown how sensitively mobile carbon pools reflect the carbon supply status of trees in cold climates. There may be an inherent lower limit to the depletion of these pools, which could restrict their usefulness as indicator values. Here we examined the responsiveness of non-structural carbohydrate (NSC) concentrations in tissues of trees which were either defoliated (removal of sources), debudded (removal of sinks) or pruned (removal of both sources and sinks) in naturally grown Pinus cembra L. at the upper treeline in the Swiss Central Alps. Complete defoliation and pruning of $66 \%$ of all branches in late winter caused a massive reduction of NSC (glucose, fructose, sucrose and starch) in all tissues during and after the following growing season, whereas $100 \%$ debudding led to a small increase of NSC, except in new buds. The NSC concentration in roots was most sensitive. Commonly, starch represented the greatest fraction of NSC. Complete defoliation before budbreak significantly reduced height growth of trees and the length of new needles; $66 \%$ pruning reduced height growth as well, but led to greater length of current-year needles. We conclude that the NSC pool in treeline trees responds to a perturbation of the source/sink balance over a wide range of NSC concentrations. Growth responses reflect the availability of carbohydrates. The seasonal variation of whole tree NSC appears to be a promising marker for testing the carbonlimitation hypothesis in treeline trees.
\end{abstract}

Keywords Carbon balance - Debudding · Defoliation · Growth $\cdot$ Non-structural carbohydrate

M.H. Li (国) · G. Hoch · C. Körner

Institute of Botany, University of Basel, Schönbeinstrasse 6, 4056 Basel, Switzerland

e-mail: maihe.li@wsl.ch

Present address:

M.H. Li, Swiss Federal Research Institute WSL,

Zürcherstrasse 111, 8903 Birmensdorf, Switzerland

\section{Introduction}

Among other reserves, non-structural carbohydrates (NSC) represent a tree's capital for growth after dormancy and act as a buffer for insufficient source activity (photosynthesis) due to adverse weather or loss of foliage. In trees, non-structural carbon is stored mainly in the form of starch, fructosans, soluble sugars and fat (triacylglycerol; Fischer and Höll 1991). Starch is the main carbohydrate storage component in conifers (Webb 1981). The size of this mobile carbon pool may be seen to reflect the balance between uptake and demand of carbon for structural growth and respiration. However, to a certain degree, plants may have a limited leeway to deplete these pools (sugars, for instance, are needed osmotically), and there may be inherent lower limits below which reserves are not exhausted, except under extreme situations. Hence, the size of the mobile carbon pool may not always hold a conclusive answer as to whether a tree's growth is carbon limited.

In the treeline debate, carbon limitation is still a possibility, though perhaps an unlikely explanation of restricted tree growth (Körner 1998, 1999). The mobile carbon pool may hold an important answer, because overabundant reserves would indicate no carbon limitation, and (periodic) depletions of these reserves would suggest insufficient supplies. However, before variations in mobile carbon pools can be interpreted in such a way, one needs to know how sensitive they are to manipulations of the source/sink ratio. To find this out was the purpose of this manipulative study.

The response to a loss of plant tissue will depend on the functional role of the damaged organs (sources or sinks; Haukioja et al. 1990; Honkanen et al. 1994). The carbon sources for growth are pools of reserve carbohydrates and currently produced photosynthate (Kramer and Kozlowski 1979), while carbon sinks are respiratory metabolism, storage of carbohydrates, structural growth and export, e.g. root exudation and mycorrhiza (Taiz and Zeiger 1991). The importance of source-sink relations in carbohydrate translocation has been demonstrated by ex- 
perimentally altering the relative strengths of sources and sinks (Kramer and Kozlowski 1979). Removal of sources or potential sinks will cause corresponding changes of photosynthesis (up- or down-regulation) in remaining or newly formed leaves, and in concentrations of mobile carbohydrates, and finally, it will affect growth rate. In general, starch concentrations were found to be reduced after both defoliation and pruning of trees (e.g. Webb and Karchesy 1977; Webb 1981; Långström et al. 1990; Agrell et al. 1999), while they remained higher than in controls after debudding (e.g. Gezelius et al. 1981). A linear, negative correlation between height increment and loss of needles was reported (e.g. Salemaa and Jukola-Sulonen 1990; Carnegie et al. 1994; Reichenbacker et al. 1996).

The growth responses of low elevation Pinus species to artificial or natural defoliation/debudding/pruning have been studied extensively (e.g. Kulman 1965, 1971; Ericsson et al. 1985; Wagner and Evans 1985; Tschaplinski and Blake 1989, 1994; Reich et al. 1993; Honkanen et al. 1994, 1999; Sanchez-Martinez and Wagner 1994; Markkola 1996; Proe et al. 2000). In Pinus just like in other taxa, defoliation causes a reduction of mobile carbohydrates (e.g. Långström et al. 1990; Vanderklein and Reich 1999) and leads to a reduction in growth (e.g. Kulman 1965; Honkanen et al. 1999). Debudding, in turn, usually stimulates both shoot expansion and needle growth, with the effect lasting for 2 years after the treatment (for Pinus sylvestris, Honkanen et al. 1994). However, no such work was conducted at the cold climate limit of tree growth.

With in situ defoliation, pruning and debudding of treeline trees we intend to test the following hypotheses:

1. Complete removal of previous needle generations (all sources) before spring growth will lead to a massive and seasonally sustained depletion of mobile carbon compounds in all tissue.

2. Pruning of two-thirds of all needled branches (sources and sinks removed) will have minor negative effects on the reserve pool.

3. Removal of all buds (the major sinks at the beginning of the growing season) will induce an overabundance of carbohydrates when compared to controls.

4. A depletion of reserve pools should be associated with diminished growth.

\section{Materials and methods}

Study sites

The experiments were conducted within the natural climatic treeline ecotone at Mont Noble $\left(46^{\circ} 12^{\prime} \mathrm{N}, 7^{\circ} 30^{\prime} \mathrm{E}\right)$, Canton Valais, Swiss Central Alps. Test trees (Pinus cembra L.) grew between 2,235 and 2,350 $\mathrm{m}$ a.s.1., on a steep NW-slope of ca. $35^{\circ}$. The root zone temperature at $10 \mathrm{~cm}$ depth averages about $6.5^{\circ} \mathrm{C}$ during the growing period (mid-May to mid-October). The mean temperature of the warmest month (July) is ca. $10^{\circ} \mathrm{C}$. The mean precipitation is ca. $630 \mathrm{~mm}$ per year, with most of this amount falling during the growing season.
Soils belong to the acid rendzina type on calcareous bedrock, with a ground cover dominated by Vaccinium myrtillus L., Empetrum hermaphroditum (Lange) Hagerup, Arctostaphylos alpina (L.) Sprengel, Loiseleuria procumbens (L.) Desv., Cladonia spp., and Cetraria islandica.

Since this was a natural treeline situation with scattered groups of trees, it was nearly impossible to find individuals of the same size and age for all treatments. However, we managed to find individuals which were fairly similar in this respect for each treatment type. These were fully insolated, healthy and undamaged specimens. All treatments were initiated on 26 May 2000, i.e. at the end of the dormant season, about 2 weeks before budbreak.

\section{Treatments and sampling}

We selected 18 trees, $0.8-3 \mathrm{~m}$ in height with $5-15 \mathrm{~cm}$ basal stem diameter at the upper end of the treeline ecotone (Kampfzone). Tree age varied between 30 and 80 years. With the substantial natural variation in tree size and the limitation in appropriate individuals, we had to group trees per treatment into classes of similar size, in order to arrive at a coherent sample per treatment.

Six trees $<1 \mathrm{~m}$ in height were used for the defoliation test, whereas 3 trees were completely defoliated by hand and 3 served as controls. Six trees between 1.5 and $2 \mathrm{~m}$ in height were used for the debudding-test ( 3 trees were completely debudded, including the apical buds and 3 served as controls). In the third group of 6 trees (about $3 \mathrm{~m}$ in height), 66\% of all needled branches were pruned in 3 individuals (e.g. 2 of 3 branches were removed at regular intervals; Spiecker 1994; Li et al. 2000, 2001a), with the remaining undamaged individuals serving as controls. Given that all 18 trees were isolated and had reached a size large enough to protrude snow cover for most of the 7-month winter period and reach full atmospheric coupling during summer (a very exposed ridge), the treatments should be readily comparable despite the different age and size of the trees. We have evidence from another study ( $\mathrm{Li}$ et al. 2001b) that intraspecific variation in NSC of a given tissue type is negligible irrespective of age/size and crown position in this class of trees, with the main variation being temporal.

\section{Sampling}

The first set of tissue samples was taken at the time of the treatment (26 May). The second and third sampling dates were on 25-26 July and 27-28 September, i.e. during the peak of shoot growth and at the end of the growing season. Buds (terminal buds of leading branches), 1- (previous year) and 2-year-old needles of leading branches of non-defoliated trees only, current-year needles (at the second and third sampling date additionally), branch wood (5- to 6-year-old xylem segments of leading branches in the lower third of the crown) and corresponding bark (only for defoliation experiment), stem wood (about $40 \mathrm{~cm}$ above the ground, using a 5-mm-diameter corer; xylem tissue only), and root wood (4- to 6-mm diameter; xylem tissue only) were collected on the SW side of each tree. All samples were immediately stored in a cool box and killed in a microwave oven $(30 \mathrm{~s}$ at $600 \mathrm{~W})$ within $7 \mathrm{~h}$ of collection. Thereafter, samples were dried to a constant weight at $75-80^{\circ} \mathrm{C}$ and were ground to fine powder.

\section{Analysis of NSC}

Starch, sucrose, glucose and fructose, for simplicity termed total non-structural carbohydrate, NSC, were analyzed using an enzymatic digest technique with subsequent spectrophotometric glucose tests (Körner and Miglieta 1994; Körner et al. 1995). After boiling samples for $20 \mathrm{~min}$ in distilled water, the soluble fraction was treated with invertase and isomerase and analyzed for glucose using a Hexosekinase reaction kit (Sigma Diagnostics, St. Louis, Mo., USA). In a second step, the insoluble material (including starch) was incubated for $20 \mathrm{~h}$ at $40^{\circ} \mathrm{C}$ with the dialyzed crude en- 
Table 1 Sugar and starch content ( $\%$ d.m.; mean values \pm SE) in tissues of treated and control trees. For simplicity we show only buds, new and 2-year-old needles, stem wood and root wood. The numbers for 1- and 2-year-old needles, and for branch and stem wood, were very similar, in both treated and control trees. Different letters indicate statistically significant $(P<0.05 ; n=3$ trees $)$ differences between treatment and control within each treatment category and date

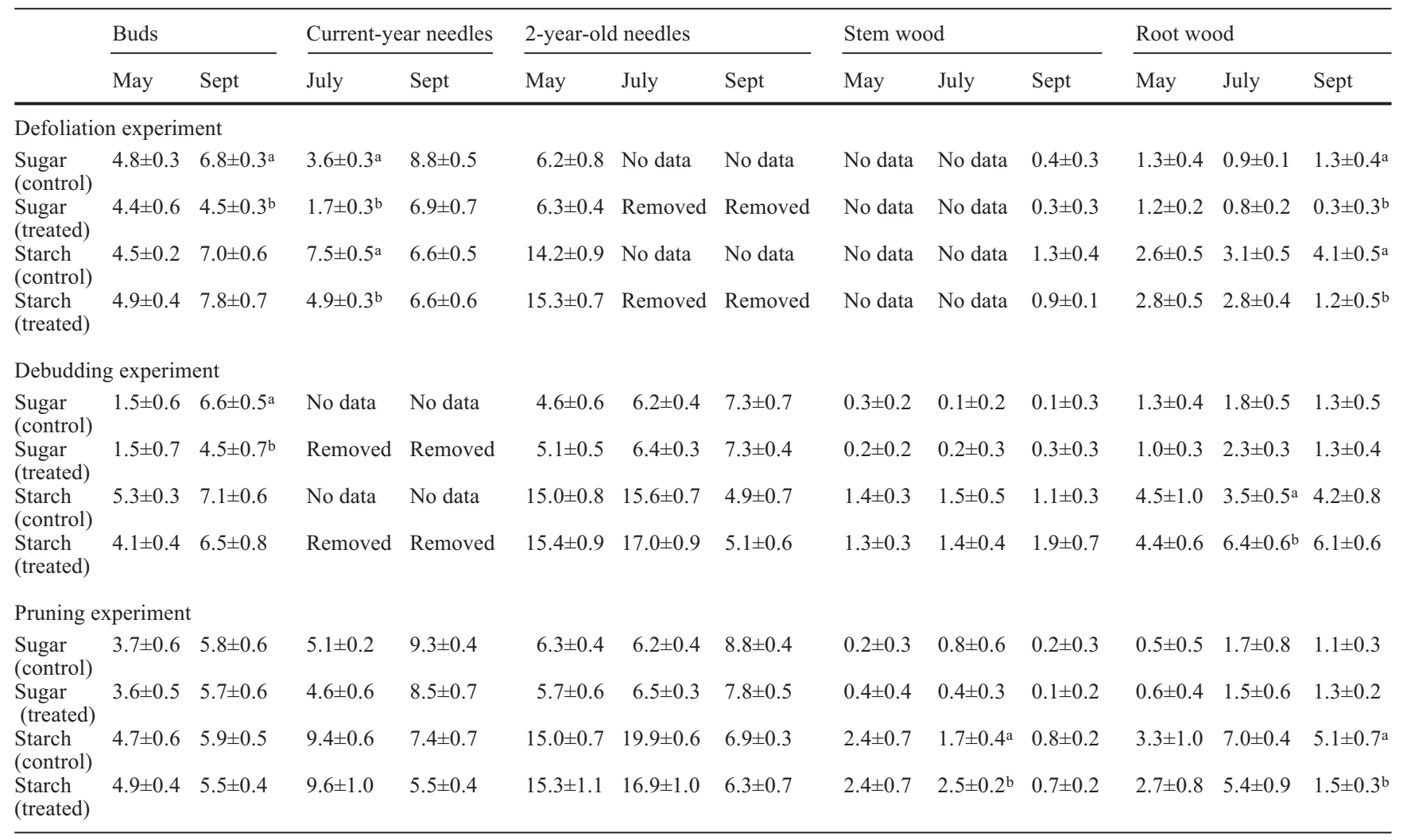

zyme Clarase (a fungal $\alpha$-amylase from Aspergillus oryzae; Miles Laboratory, Elkhart, Ind., USA). Starch and sugar standards as well as a laboratory standard of plant powder were used as controls for all analyses. Carbohydrates other than starch, sucrose, fructose and glucose are not covered by this assay. From detailed gas chromatographic analysis we know that our analysis misses a small raffinose and stachyose fraction $[\leq 1.3 \%$ of dry matter (d.m.)], and a slightly bigger fraction, in essence restricted to needles, of pinitol $(\leq 3.2 \%$ of d.m.; hence, we cover $75-95 \%$ of the mobile carbohydrate pool in all sampled tissues; G. Hoch, unpublished data). The sugar, starch and NSC concentrations (\%) were calculated on a d.m. basis.

\section{Data analysis}

Concentrations of NSC and its components were statistically tested per sampling date with a single-factor ANOVA. Since we are interested in the responses at a discrete developmental stage, a time series analysis would not be appropriate. Diagrams show means \pm SE bars for 3 replicate trees per organ. Except for Table 1, we present only NSC, which in essence reflects variations in starch, while the sugar concentration hardly differed between treatment and control at each sampling date.

\section{Results}

The initial NSC concentration and its components sampled on 26 May (end of the dormant season, just before treatments) did not differ among experimental trees (Fig. 1, and Table 1).

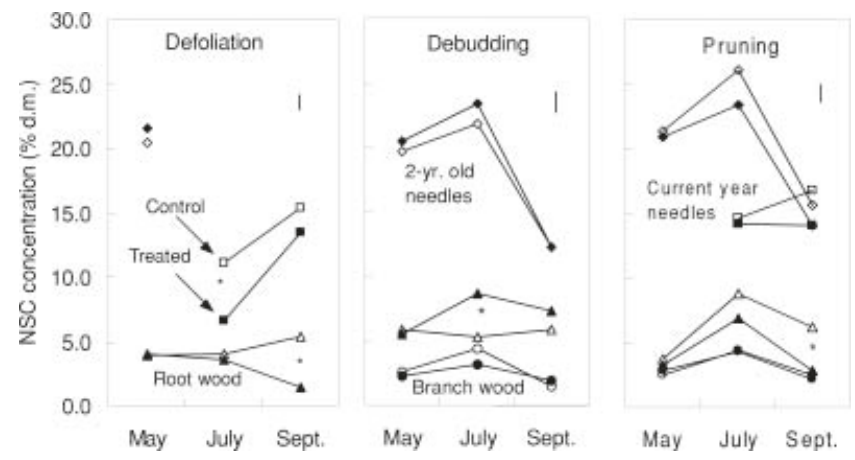

Fig. 1 Seasonal variation of non-structural carbohydrate (NSC) concentration in different tissues of control and treated trees. Data for needles in the upper part and for xylem of branches and roots in the lower part. For the sake of clearness, we omitted data for buds, 1-year-old needles and stem wood, since the seasonal NSC variation in 1- and 2-year-old needles, and in stem and branch xylem was very similar, for both treated and control trees. We also omitted the data for branch wood in the defoliation experiment, since they showed no difference and are similar to those in the debudding experiment. The mean standard error $(2 \times \mathrm{SE})$ for each experiment is shown in the upper right-hand corner (small bar). Asterisks indicate significant differences $(P<0.05)$ 
Fig. 2 Effects of defoliation, debudding and pruning on the total NSC concentration of tissues at the end of the treatment season $(* P<0.05$, ** $P<0.01$, $* * * P<0.001)$
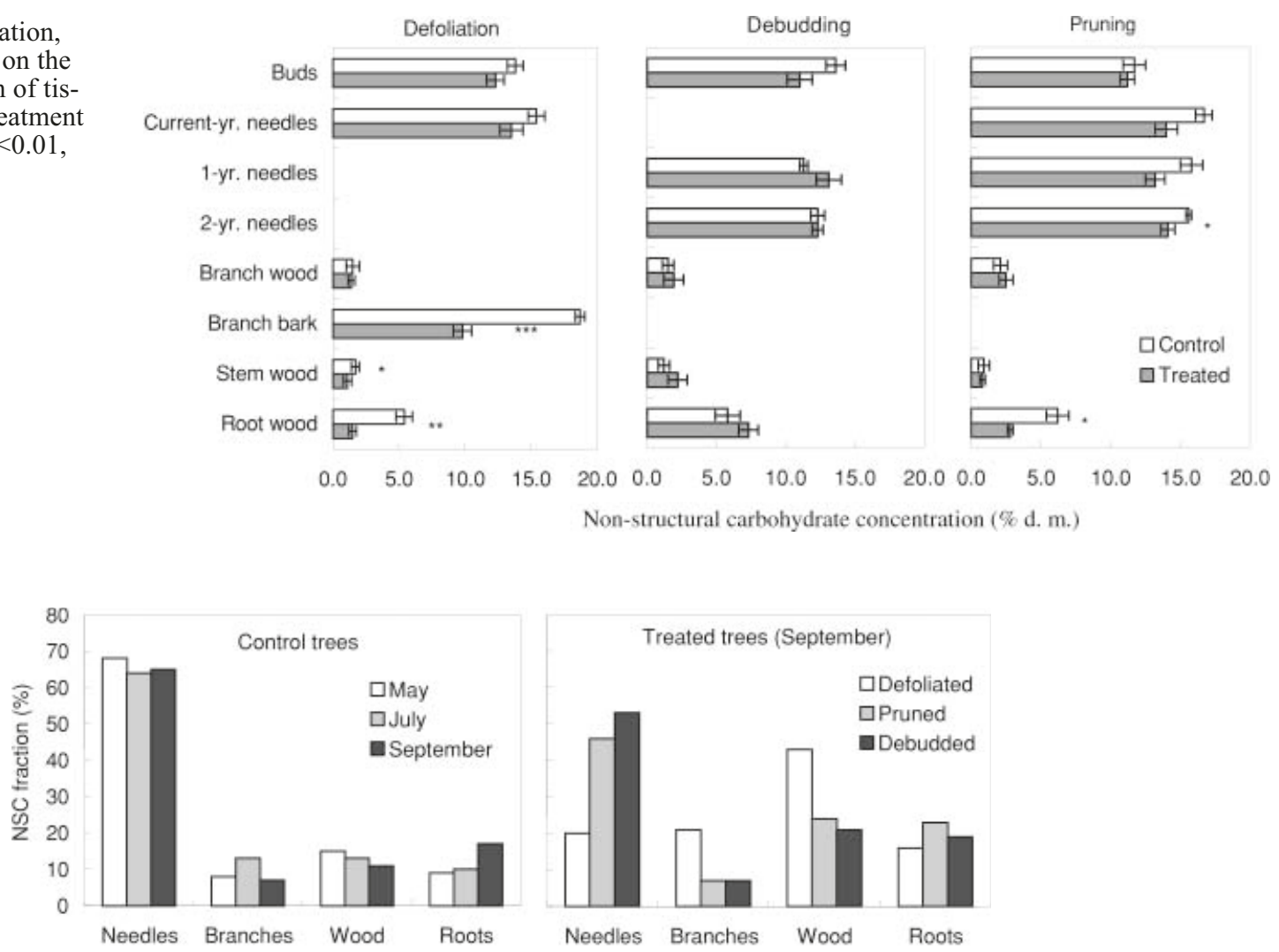

Fig. 3 The contribution of different organs to the total NSC pool $(100 \%)$ of trees. NSC fractions were calculated using biomass fractions measured by Bernoulli and Körner (1999) and Li (1999) on trees of similar size. The NSC fraction of buds was omitted because of their very small biomass fraction. No data for bark biomass fraction were available, hence NSC in bark was disregarded here. Note the dramatic reduction in needle NSC fraction in defoliated trees, which causes the relative contribution of all other fractions to increase

\section{Effects of defoliation}

Complete defoliation caused a reduction of NSC concentrations in all tree tissues during (Fig. 1) and at the end (Fig. 2) of the growing season. However, organs responded differently, i.e. the major (highly significant) effects on NSC were found in roots, stem wood and branch bark (Fig. 2) and in newly formed (current) needles, whereas only minor (n.s.) effects occurred in branch wood and buds (Fig. 1). For instance, at the peak of the growing period, current-year needles were most affected ( $-53 \%$ for sugars, $-35 \%$ for starch and $-41 \%$ for NSC, all $P<0.01$; Table 1). After the growing season, there was a significant reduction in sugar $(-80 \% ; P<0.05)$, starch $(-71 \% ; P<0.01)$ and NSC $(-72 \% ; P<0.05)$ concentration in roots, in stem wood $(-47 \%$ NSC, $P<0.01)$ and a very significant decrease in NSC in branch bark $(-47 \%$, $P<0.001)$. Complete defoliation affected the NSC concentration mainly in newly formed needles at the peak of the growing period (Table 1), and in sinks (branch bark, wood of stems and roots) at the end of the growing season (Fig. 2).

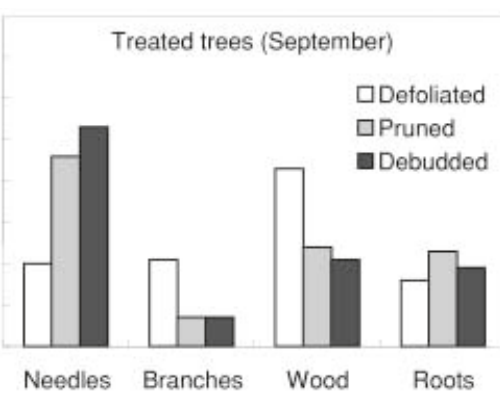

Tree height increments and new needle growth were significantly reduced after defoliation by the end of the season. Apical growth in defoliated trees was only $22 \%$ of that in controls (1.8 instead of $8.2 \mathrm{~cm}, P<0.001)$. Current-year needle length of defoliated trees was 1.4 and $3.0 \mathrm{~cm}$ on 25 July and 28 September, respectively, whereas it was 3.7 and $6.1 \mathrm{~cm}$ in control trees $(P<0.001$ for both dates). The length increment between these two dates was $1.6 \mathrm{~cm}(53 \%$ of the final length) in treated trees, and $2.4 \mathrm{~cm} \mathrm{(39 \%} \mathrm{of} \mathrm{the} \mathrm{final} \mathrm{length)} \mathrm{in} \mathrm{con-}$ trols.

\section{Effects of debudding}

Complete debudding caused no significant changes in NSC concentration in any tissue type after a treatment season, but there was a uniform trend of slightly higher values, except in newly formed buds (Fig. 2). Seasonal patterns of the NSC response showed an increasing trend from the beginning to the mid-season, and then a decreasing effect until the end of the growing period (Fig. 1). Although there was a significant increase of starch $(+83 \%, P<0.05)$ and NSC $(+64 \%, P<0.01)$ in roots of debudded trees compared with controls in July (Table 1), this difference had nearly disappeared by the end of the growing season (Fig. 2).

No measurements of tree growth can be given for this treatment, because $100 \%$ debudding prevented the formation of new shoots and needles during the 2000 growing season. 
Effects of pruning

Removal of $66 \%$ of all needled branches before the onset of the growing season reduced NSC concentration during the season (Fig. 1), but at the end of the season the effect was significant only for roots $(-71 \%$ starch, $P<0.05$, Table $1 ;-55 \%$ NSC, $P<0.05$, Fig. 2) and for 2 -year-old needles $(-10 \%$ NSC, $P<0.05$; Fig. 2$)$. NSC concentrations were highest in July and declined as the season progressed (Fig. 1, Table 1).

Pruning caused the length of current-year needles on remaining branches to increase by $+17 \% \quad(P<0.001)$, whereas the apical shoot growth tended to decline (-24\%, but n.s.).

\section{Discussion}

\section{Carbon balance}

Removal of sources ( $100 \%$ defoliation) and removal of both sources and sinks (66\% pruning of total branches) caused a reduction of NSC concentration in all tissues of treated trees during and after the first growing season compared with that of controls, except for branch wood of pruned trees. In contrast, removal of sinks $(100 \%$ debudding) caused an overall increase of NSC concentration in all tissues (except in regrowth buds), but this effect was not significant at the $5 \%$ level. The NSC concentrations in roots were affected most in all three treatments. Of the three treatments, $100 \%$ defoliation had the most pronounced effects on NSC. The massive depletion of NSC pools after defoliation is in line with hypothesis 1 . However, given the severity of the manipulation, we were surprised by the amount of storage reserves accumulated by September, after a new needle cohort had been established. After the growing season, defoliated trees showed the strongest NSC reduction in roots $(-72 \%)$ and the smallest reduction in newly formed needles $(-12 \%)$. The concurrent growth restriction to only one-fifth of the height growth of control trees indicates a shortage of carbon for structural growth and reserve formation. There are several examples for carbohydrate responses to defoliation in trees. For Pinus sylvestris, Honkanen et al. (1999) reported that defoliation significantly lowered concentrations of fructose $(-15 \%)$ and glucose $(-17 \%)$ in new needles. In Pinus resinosa, 50\% defoliation was found to significantly reduce starch contents of whole-seedlings by ca. $-50 \%$ (Vanderklein and Reich 1999). In the Austrian Alps, Bauer et al. (2000) found an up to $40 \%$ reduction of NSC concentration in all organs, except for roots in Picea abies by mid-August after a ca. $70 \%$ loss of current-year needles due to Chrysomyxa rhododendri infection. Similar responses to defoliation were reported for deciduous trees (e.g. Heichel and Turner 1976; Coffelt et al. 1993).

Complete debudding caused only a slight increase in NSC (hypothesis 3). Hence, debudding effects were smaller than we expected, suggesting that trees had little leeway toward further NSC accumulation in the absence of new shoot growth. Our data on bud removal effects are in line with those by Gezelius et al. (1981) for Pinus sylvestris seedlings and by Tschaplinski and Blake (1994) for Populus maximowiczii x nigra. In both cases no or only non-significant effects on starch concentration in the stem were detected. In Pinus sylvestris, Honkanen et al. (1999) reported a non-significant increase of fructose and glucose, even a small reduction of sucrose after sink removal. Hence, sink removal seems to have little effect on reserve pools.

Pruning had minor negative effects on the reserve pool in line with hypothesis 2 . Other studies also reported a general decline in starch reserves after pruning (e.g. Webb and Karchesy 1977, in Pseudotsuga menziesii; Ericsson et al. 1980, 1985, in Pinus sylvestris). Similarly, Långström et al. (1990), who pruned Pinus sylvestris corresponding to ca. $20 \%$ loss of needles, found less starch $(-25 \%)$ in 2-year-old needles, both in young (25 years old) and old trees (60 years).

Using data for biomass fractionation $(21 \%$ for needles, $19 \%$ for branches, $47 \%$ for wood and $13 \%$ for roots) in intact young Pinus cembra from the alpine treeline by Bernoulli and Körner (1999) and Li (1999), we estimated the relative contribution of different organs to the total NSC pool of trees (Fig. 3). Needles contain the largest NSC fraction in controls (64\% in May and $68 \%$ in September). Hence, removing needles not only means removal of C-assimilation capacity, but also elimination of the largest carbon reserve fraction. NSC in roots, which was most sensible to source-sink perturbation, comprises only 9\% (in May) and 17\% (in September) of the mobile $\mathrm{C}$ pool in intact trees due to both the relatively small biomass fraction and low mean NSC concentration. Hence, the variation in root reserves had little effect on the whole tree NSC pool (Fig. 3). In contrast, the loss of needles had a massive effect on the whole tree NSC pool because of both their high NSC concentration and biomass contribution.

\section{Growth responses}

In line with our hypothesis 4, all three treatments reduced extension growth, a common observation in trees which have lost part or all of their foliage or buds (for Picea abies Salemaa and Jukola-Sulonen 1990; for Eucalyptus sp. Carnegie et al. 1994; for Populus sp. Reichenbacker et al. 1996; and for various deciduous tree species, Li et al. 2000). A ca. 25\% reduction of needle length was observed by Honkanen et al. (1999) on defoliated branches of Pinus sylvestris, and a marked reduction of leaf size is known for deciduous trees as well (Heichel and Turner 1976; Faeth 1992). The increased length of current-year needles in pruned trees may reflect a growth response to the unbalanced source-sink relationship. The reduction in height growth possibly resulted from reduced carbon fixation, and in the case of debudding, the loss of the apical meristem. 


\section{Conclusion}

This study demonstrated the responses of treeline trees to $100 \%$ defoliation, $100 \%$ debudding and $66 \%$ pruning of branches in Pinus cembra. Overall our data illustrate that mobile carbohydrate pools in treeline trees are similarly responsive to source/sink perturbations, as was observed in lowland trees. The fact that the complete removal of sources had much more pronounced effects than the removal of sinks or both sinks and sources is not surprising. However, it is remarkable that these massive interventions by far did not exhaust reserves, and part of the initial depletion was already replaced by the end of the short and cold growing season at treeline. Since in our case needles represent the largest fraction of the trees' NSC pool and have a life expectancy of 5-7 years, their total removal is unlikely to be tolerated twice, i.e. in the subsequent season. On the other hand, "bud break and sprouting in spring is exclusively supplied by the recent photosynthates of the previous year's needles" (Hansen and Beck 1994, p 172). Hence, the loss of all old needles enforces early autotrophy of emerging needles, leaving little to export for tree growth, as we have seen. Trees with a full leaf canopy but no shoot buds accumulated very little additional NSC. It almost seems like there was no leeway to accumulate even more reserves than were already present (so hypothesis 3 was disproved, despite a small non-significant stimulation).

The results of this analysis support the usefulness of NSC assessments for identifying potential source limitation in treeline trees. The tree NSC pool is indeed sensitive to such disturbances. However, on the basis of what we have seen here, the probability of whole tree carbon limitation of tree growth near the upper tree limit appears small as long as the leaf canopy is not destroyed.

Acknowledgements This project was funded by the Swiss National Science Foundation, project no. 31-55173.98, to C. Körner. We gratefully acknowledge the help in NSC analysis by O. Bignucolo, G. Schaer, B. Steullet-Müller and the support given by J. Paulsen during the field work.

\section{Reference}

Agrell J, McDonald EP, Lindroth RL (1999) Responses to defoliation in deciduous trees: effects of $\mathrm{CO}_{2}$ and light. Ecol Bull 47:84-95

Bauer H, Plattner K, Volgger W (2000) Photosynthesis in Norway spruce seedlings infected by the needle rust Chrysomyxa rhododendri. Tree Physiol 20:211-216

Bernoulli M, Körner Ch (1999) Dry matter allocation in treeline trees. Phyton 39:7-12

Carnegie AJ, Keane PJ, Ades PK, Smith IW (1994) Variation in susceptibility of Eucalyptus globulus provenances to mycosphaerella leaf disease. Can J For Res 24:1751-175

Coffelt MA, Schultz PB, Wolf DD (1993) Impact of late-sea son orangestriped oakworm (Lepidoptera: Saturniidae) defoliation on oak growth and vigor. Environ Entomol 22:13181324

Ericsson A, Larsson S, Tenow O (1980) Effects of early and late season defoliation on growth and carbohydrate dynamics in Scots pine. J Appl Ecol 17:747-769
Ericsson A, Hellqvist C, Långström B, Larsson S, Tenow O (1985) Effects on growth of simulated and induced shoot pruning by Tomicus piniperda as related to carbohydrate and nitrogen dynamics in Scots pine. J Appl Ecol 22:105124

Faeth SH (1992) Do defoliation and subsequent photochemical responses reduce future herbivory on oak trees. J Chem Ecol 18:915-925

Fischer CH, Höll W (1991) Food reserves of Scots pine (Pinus sylvestris L.). I. Seasonal changes in the carbohydrate and fat reserves of pine needles. Trees 5:187-195

Gezelius K, Ericsson A, Hällgren JE, Brunes L (1981) Effects of bud removal in Scots pine (Pinus sylvestris) seedlings. Physiol Plant 51:181-188

Hansen J, Beck E (1994) Seasonal changes in the utilization and turnover of assimilation products in 8-year-old Scots pine (Pinus sylvestris L.) trees. Trees 8:172-182

Haukioja E, Ruohomäki K, Senn J, Suomela J, Walls M (1990) Consequences of herbivory in the mountain birch (Betula pubescens ssp. tortuosa): importance of the functional organization of the tree. Oecologia 82:238-247

Heichel GH, Turner NC (1976) Phenology and leaf growth of defoliated hardwood trees. In: Anderson JF, Kaya HK (eds) Perspectives in forest entomology. Academic Press. New York, pp 31-40

Honkanen T, Haukioja E, Suomela J (1994) Effects of simulated defoliation and debudding on needle and shoot growth in Scots pine (Pinus sylvestris): implications of plant source/sink relationships for plant-herbivore studies. Funct Ecol 8:631639

Honkanen T, Haukioja E, Kitunen V (1999) Responses of Pinus sylvestris branches to simulated herbivory are modified by tree sink/source dynamics and by external resources. Funct Ecol $13: 126-14$

Körner C (1998) A re-assessment of high elevation treeline positions and their explanation. Oecologia 115:445-459

Körner C (1999) Alpine plant life. Springer, Berlin Heidelberg New York

Körner C, Miglietta F (1994) Long term effects of naturally elevated $\mathrm{CO}_{2}$ on Mediterranean grassland and forest trees. Oecologia 99:343-351

Körner C, Pelaez-Riedl S, van Bel AJE (1995) $\mathrm{CO}_{2}$ responsiveness of plants: a possible link to phloem loading. Plant Cell Environ 18:595-600

Kramer PJ, Kozlowski TT (1979) Physiology of woody plants. Academic Press, Orlando, Florida, USA

Kulman HM (1965) Effects of artificial defoliation of pine on subsequent shoot and needle growth. For Sci 11:90-98

Kulman HM (1971) Effects of insect defoliation on growth and mortality of trees. Annu Rev Entomol 16:289-324

Långström B, Tenow $\mathrm{O}$, Ericsson A, Hellqvist C, Larsson S (1990) Effects of shoot pruning on stem growth, needle biomass, and dynamics of carbohydrates and nitrogen in Scots pine as related to season and tree age. Can J For Res 20:514-523

Li MH (1999) Grundlagen zur Hochlagenaufforstung im Einzugsgebiet des Yangtse als Beitrag zur Hochwasservorbeugung unter Mitberücksichtigung von Forschungsergebnissen in den Alpen. Dissertation, Universität für Bodenkultur, Vienna, Austria

Li MH, Uehre P, Körner C, Matschke J (2000) Einfluss der Grünästung auf das kurzfristige Dickenwachstum und die Wachstumsdynamik. AFZ/Der Wald 25:1348-1350

Li MH, Uehre P, Matschke J (2001a) Dickenzuwachs und Stammform in Abhängigkeit von Entastungsintensitäten der Bäume. Schweiz Z Forstwes 152:389-393

Li MH, Hoch G, Körner C (2001b) Spatial variability of mobile carbohydrates within Pinus cembra trees at the Alpine treeline. Phyton 41:203-213

Markkola AM (1996) Effect of artificial defoliation on biomass allocation in ectomycorrhizal Pinus sylvestris seedlings. Can J For Res 26:899-904 
Proe MF, Mead DJ, Byrne D (2000) Effect of pruning on nitrogen dynamics within crowns of Pinus radiata. Tree Physiol 20:653-661

Reich PB, Walters MB, Krause SC, Vanderklein DW, Raffa KF, Tabone T (1993) Growth, nutrition and gas exchange of Pinus resinosa following artificial defoliation. Trees 7:67-77

Reichenbacker RR, Schultz RC, Hart ER (1996) Artificial defoliation effect on Populus growth, biomass production, and total nonstructural carbohydrate concentration. Environ Entomol 25:632-642

Salemaa M, Jukola-Sulonen EL (1990) Vitality rating of Picea abies by defoliation class and other vigour indicators. Scand J For Res 5:413-426

Sanchez-Martinez G, Wagner MR (1994) Sawfly (Hymenoptera: Diprionidae) and artificial defoliation affects above- and below-ground growth of ponderosa pine seedlings. J Econ Entomol 87:1038-1045

Spiecker M (1994) Wachstum und Erziehung wertvoller Waldkirschen. Mitt Forstl Versuchs- Forschungsanst Baden-Württemberg 181
Taiz L, Zeiger E (1991) Plant physiology. The Benjamin/ Cummings, Redwood City, Calif.

Tschaplinski TJ, Blake TJ (1989) The role of sink demand in carbon partitioning and photosynthetic reinvigoration following shoot decapitation. Physiol Plant 75:166-173

Tschaplinski TJ, Blake TJ (1994) Carbohydrate mobilization following shoot defoliation and decapitation in hybrid poplar. Tree Physiol 14:141-151

Vanderklein DW, Reich PB (1999) The effect of defoliation intensity and history on photosynthesis, growth and carbon reserves of two conifers with contrasting leaf lifespans and growth habits. New Phytol 144:121-132

Wagner MR, Evans PD (1985) Defoliation increases nutritional quality and allelochemics of pine seedlings. Oecologia 67: $235-237$

Webb WL (1981) Relation of starch content to conifer mortality and growth loss after defoliation by the Douglas-fir tussock moth. For Sci 27:224-232

Webb WL, Karchesy JJ (1977) Starch content of Douglas-fir defoliated by the tussock moth. Can J For Res 7:186-188 